\title{
Effect of Intake Air Temperature, Pressure And Fuel Injection Pressure On Low Temperature Combustion (LTC) Engine BY Using Dual Injection Strategy For Pollution Reduction
}

Bharathiraja Moorthy ( $\sim$ bharathiraja@bitsathy.ac.in )

Bannari Amman Institute of Technology https://orcid.org/0000-0003-1021-1840

Nithyanandhan Kamaraj

Kongu Engineering College

Somasundaram Periasamy

Kongu Engineering College

Saji Raveendran Padmavathy

Kongu Engineering College

Gaurav Dwivedi

Maulana Azad National Institute of Technology

Ranjithkumar Subramaniam

Kongu Engineering College

\section{Research Article}

Keywords: Low temperature combustion, split injection, injection pressure, injection angle, air fuel charge temperature

Posted Date: July 8th, 2021

DOI: https://doi.org/10.21203/rs.3.rs-593550/v1

License: (c) (i) This work is licensed under a Creative Commons Attribution 4.0 International License. Read Full License 


\section{Abstract}

Starting from the invention of engines, automobiles require engines for their application. Even though several alternatives have been proposed like fuel cells, engines play the vital role in the automobile sector. In this scenario, the emissions coming out from the engine contributes to the global air pollution at an unbelievable rate. This led the government to enforce strict emission regulations on automobiles. To achieve those regulations several ideas have been proposed so far, which are generally classified into two categories as in-cylinder measures and after-treatment measures. But the thing is after-treatment measures are too costly and also it mainly depends on combustion rate. So obviously in-cylinder controls will be the potential area for the research. Automobile sector not only focused on emissions; it also wants high thermal efficiency in engine. Due to high thermal efficiency and good fuel economy diesel engines are the favorite one in automobiles. But it emits NOx and PM at higher rate. To overcome this issue low temperature combustion (LTC) concept is introduced, added to the objective it can also maintain high thermal efficiency as like as diesel combustion. The problem regarding to LTC are combustion phasing control, transient operations, limited operating range and mainly it contributes to $\mathrm{HC}$ and $\mathrm{CO}$ emissions while concentrating on reduction of NOx and PM. In the present work, control emissions and combustion phasing of LTC combustion concept by dual injection strategy was studied and the effect of fuel injection pressure, intake air temperature and pressure also studied. The project was done only on partial load with diesel as fuel. Late injection strategy of LTC was used. Results shown that compared to single injection strategy, thermal efficiency was improved by dual injection strategy. Pilot injection timing and mass fraction played a vital role in controlling emissions and improving thermal efficiency. In all intake air temperature, if fuel injection pressure increase result in increase of thermal efficiency, $\mathrm{NO}$ emission and decrease of smoke, $\mathrm{CO}$ and $\mathrm{HC}$ emissions. Likewise in all intake air temperature and fuel injection pressure, if Intake air pressure increase result in increase of thermal efficiency, smoke and decrease of NO, HC and CO emissions. Maximum Indicated thermal efficiency achieved was $38 \%$ which was $8 \%$ higher than base readings. Lowest NO emission achieved was 187 ppm, that was $68 \%$ less than base reading. Lowest smoke achieved was $3 \%$ of opacity, which was $75 \%$ less than base reading. An overall comparing result, optimized fuel injection pressure is 600 bar, intake air temperature is $310 \mathrm{~K}$, intake air pressure is $107 \mathrm{kPa}$. At that condition, smoke reduced to $23 \%$, NO reduced to $63 \%$, CO reduced to $75 \%$ and indicated thermal efficiency increased to $4 \%$ compare to base readings.

\section{Introduction}

In the 21st century, automobiles are extensively used. Conventional fuels like diesel and gasoline demands are increased day by day and in future, demand reaches peak level. In present, fuel cost also increasing and people also focus on reduction of greenhouses gases. This put pressure to evolve new engine technology with an engine having high efficiency. Already, diesel engines ( $\mathrm{Cl}$ Engine) having high efficiency than petrol engines (SI Engine). so people are working more on diesel Engines ( $\mathrm{Cl}$ Engine). Major $\mathrm{Cl}$ engine emissions are $\mathrm{NO}_{\mathrm{x}}$ and soot. Owing to their harmful effects on the atmosphere as well as on human health, pollutants emitted by engines are a major concern. In addition, existing and future regulations set down strict standards on exhaust emissions.

Current advance $\mathrm{Cl}$ engine does not withstand these emission norms, so the only way is to go for alternate combustion technology like $\mathrm{HCCl}$ (Homogeneous Charge Compression Ignition engine), PCCI (Partial /Premixed Charge Compression Ignition engine), RCCl (Reactive Controlled Compression Ignition) and LTC (Low-Temperature Combustion). Euro norms are shown in Fig. 1.1, it clearly denotes how $\mathrm{NO}_{\mathrm{x}}$ and soot have been narrow down. LTC combustion technology operates at low temperature and forms homogeneous charge mixture of air and fuel which reduce both $\mathrm{NO}_{\mathrm{x}}$ and soot simultaneously.Presently a day, a few US inquire about lab generally supported by U.S. Office of Vitality (U.S. DOE) are closely included in LTC combustion investigate. For occurrence Argonne National Lab (ANL), Sandia National Lab (SNL), Lawrence Barkley National Lab [LBNL] and Oak Edge, National Lab (ORNL) are among the foremost noteworthy, but there are few challenges to overcome in case this innovation wanted to execute it within the future. 
John E. Dec (2009) explored in-cylinder forms in progressed compression-ignition engines and provide progressed compression-ignition (Cl) engines give both tall efficiencies and exceptionally moo NOX and particulate (PM) outflows. Efficiencies are comparable to customary diesel engines, but not at all like customary diesel engines, the charge is profoundly weakened and premixed (or in part premixed) to realize moo emanations. Weakening is finished by working either incline or with huge sums of EGR. To get weaken LTC, this approach depends on tall levels of EGR, and injection timing is ordinarily moved 10-15CA prior or afterward than for customary diesel combustion so temperatures are lower, which delays start and gives more time for premixing. In spite of the fact that these progressed $\mathrm{Cl}$ combustion modes have vital preferences, there are troubles in executing them in down to earth engines. Advance in this article surveyed the standards of $\mathrm{HCCl}$ and diesel LTC engines alongside the comes about of investigating on the in-cylinder forms, overcoming the most challenges confronting these engines, counting: progressing low-load combustion proficiency, expanding the high-load restrain, understanding fuel impacts, and keeping up moo NOX and PM outflows over the working extend. Santiago Molin et al (2005) examined the Low Temperature Combustion of Light-Duty Diesel Engines and clarify the possibility of getting moo temperature mixing-controlled combustion (mixing-controlled LTC) in a little $\mathrm{HSDI}$ engine with the objective of maintaining a strategic distance from concurrent $\mathrm{NO}_{\mathrm{x}}$ and sediment arrangement. This mixing-controlled LTC methodology is based on decreasing the comparability proportion at the lift-off cross-section conjointly the nearby combustion temperatures but keeping up the customary diesel shower structure. Assist a parametric think about also carried out to assess the impacts of in-cylinder gas thickness, temperature, and oxygen concentration on the characteristics of the mixing-controlled LTC characteristics. Moo $\mathrm{NO}_{\mathrm{x}}$ and moo sediment mixingcontrolled diesel combustion have been accomplished by combining moo in-cylinder gas temperatures along with tall discuss densities and moo oxygen concentrations. Xingcai Lu et al (2015) looked into Fuel plan and administration for the control of progressed compression-ignition combustion modes and clarified the foremost unmistakable characteristic of unused combustion modes, such as Homogenous-Charge Compression-Ignition ( $\mathrm{HCCl})$, Stratified-Charge Compression-Ignition (SCCI), and Low-Temperature Combustion (LTC), is the prerequisite of making a homogenous blend or controllable stratified blend earlier to start and incline fuel/air blend and/or a controllable tall level of debilitate gas distribution (EGR) are utilized to drag out the timescale of the start chemistry and harbour fuel injection or early incylinder injection is utilized to stretch the blending period. The blend at that point experiences controlled self-ignition close the beat dead centre (TDC) position due to the compression impact of the piston's upward development.It is worth noticing that the complete combustion preparation needs a coordinated strategy for the control of start timing and combustion rate, which are instep controlled basically by chemical energy and, to a lesser degree, by turbulence and blending. Since of the noteworthy impacts of fuel physical, chemical properties on the start and combustion handle, fuel design and administration has ended up the foremost common approach for the control of start timing and combustion rate in such progressed combustion modes, at long last summarizes the concepts and strategies of fuel plan and administration and gives a diagram of the impacts of these techniques on start, combustion, and emanations for $\mathrm{HCCl}$, LTC, and SCCl engines. LTC has three sorts of fuel injection procedures. D. Ganesh et al (2013) was conducted an exploratory Examination of the Homogeneous Charge Compression Start Combustion of Biodiesel Fuel with Outside Blend Arrangement in a $\mathrm{Cl}$ engine. Fuel was infused in the harbour itself. The test was conducted on the single cylinder coordinate injection diesel engine with a consistent speed of $1500 \mathrm{rpm}$ and performed at a changing stack. The fuel utilized was jatropha methyl ester and this fuel has a tall oxygen substance. Fuel vaporizer framework was utilized to create fuel discuss blend remotely. Cooled EGR utilized up to $30 \%$ comes approximately found that $\mathrm{HC}$ and $\mathrm{CO}$ outpourings were lower compared to standard due to the closeness of oxygen inside the fuel structure itself and warm effectiveness, BMEP decreased since of fuel divider wetting inside the harbour and spatial combustion within the cylinder. Pranab Das et al (2015) explored the impact of fundamental injection timing for controlling the combustion staging of a homogeneous charge compression start engine employing a modern double injection methodology. The try was conducted on a Single cylinder $\mathrm{Cl}$ engine with a coordinate injection at steady speed $1350 \mathrm{rpm}$ and injection weight at 200 bars.Fuel used was commercial diesel. Dual injection strategies were used, the first injection was injected too early 270 deg. bTDC had $80 \%$ of fuel volume and second injection at varying crank angle $26,23,20,17,14,11,8^{\circ} \mathrm{CA}$ bTDC 
had remaining fuel volume. The test took at diverse stack $45 \%$ and $60 \%$ and comes about were compared with customary diesel operation. The comes about appeared that impeding of the moment injection, Top weight diminishes for both loads. PRR and HRR shift towards TDC and reduced its value. Combustion duration reduced up to the second injection $14^{\circ} \mathrm{CA}$ bTDC than increased. Starts of combustion highly depended on injection timing at $45 \%$ load and at $60 \%$ load it highly depended on premixed equivalence ratio. Engine with $45 \%$ load $\mathrm{HC}$ and $\mathrm{CO}$ increase due to fuel and air mixture enter into crevice volume and combustion took at low temperature. $\mathrm{HC}$ and $\mathrm{CO}$ emission was normally found higher in all operating condition. The try incorporates a downside as Lower brake warm proficiency, Higher BSFC, HC, and CO outflows than the pattern.Ali Turkcan et al(2013)also investigated early injection but fuels used were gasoline and alcohol blend E10 (Ethanol 10\%), E20 (Ethanol 20\%), M10 (Methanol 10\%) and M20 (Methanol 20\%). gasoline and alcohol. The test was conducted on single cylinder engine with direct injection at a constant speed of $1100+-20 \mathrm{rpm}$ and had intake air temperature $100^{\circ} \mathrm{C}$ and injection pressure at $10 \mathrm{Mpa}$. Dual injection strategies were used, the first injection at $240^{\circ} \mathrm{CA}$ bTDC had $80 \%$ of fuel volume and second injection at varying crank angle $15,20,25,30^{\circ} \mathrm{CA}$ bTDC. The test took at two proportionality proportions $45 \%$ and $60 \%$ and comes about were compared with customary diesel operation. The comes about appeared that the combustions and outflows were controlled by the moment injection, in all test conditions and fills utilized. Expanding ethanol mix would diminish most extreme weight, $\mathrm{PRR}, \mathrm{HRR}$, and $\mathrm{NO}_{\mathrm{x}}$ values and it impedes timing of begins of combustion, most extreme weight area, and CA 50 at moo and tall comparability proportion. Expanding Methanol mix would raise the greatest weight, PRR, HRR, and $\mathrm{NO}_{\mathrm{x}}$ values and it progressed timing of begins of combustion, the greatest weight area, and CA 50 at moo and tall proportionality proportion. PRR of liquor mix was closer to thump restrain at tall proportionality proportion. Liquor mixes had shorter combustion length at tall proportionality proportion and long combustion length at moo comparability proportion. $\mathrm{HC}$ and $\mathrm{CO}$ were influenced less by the moment injection compared to $\mathrm{NO}_{x}$ and smoke. Lower $\mathrm{NO}_{x}, \mathrm{HC}, \mathrm{CO}$, outflow, and higher IMEP and warm productivity were accomplished by utilizing ideal moment fuel injection timing for liquor mixes at moo comparability proportion. The smoke of liquor mixes was lower than gasoline for impeding moment injection and higher than gasoline for progress moment injection. $\mathrm{NO}_{\mathrm{x}}$ decreased without a drop in IMEP and warm proficiency for all test fuels. $\mathrm{K}$. Mathivananet al (2016)explored the Impact of numerous fuel injection procedures on execution and combustion characteristics of a diesel-fuelled $\mathrm{HCCl}$ engine. The test was conducted on 4- cylinder engine at consistent speed 1800 rpm, consistent stack 3 bars (IMEP), and injection weight 1200 bar (add up to a term of fuel injection 1765+-1 microsecond), and with admissions weight and temperature $1 \mathrm{bar}$ and $25^{\circ} \mathrm{C}$. Fuel used was commercial diesel. Multiple fuel injection technique was used. The fuel injected in five pulses with timing start from $100^{\circ} \mathrm{CA} \mathrm{bTDC}$ and other pulses injected in regular interval of $10^{\circ} \mathrm{CA}$ after previous injection. There were two phases of experiments were conducted. In phase 1 , first pulse duration changed in the sequence of 274,304 and 334 micro second with varying late pulse timing in the manner of 20,10,0 CA bTDC. In phase 2, late pulse duration changed in the sequence of 274, 304 and 334 micro second with varying late pulse timing in the manner of $20,10,0^{\circ} \mathrm{CA}$ bTDC. Results were compared to single injection $\mathrm{HCCl}$ and conventional diesel mode. In phase 1 results, as first injection duration raises HRR reduced its value and retard its timing, $\mathrm{NO}_{\mathrm{x}}$ and soot emissions got reduced, $\mathrm{HC}$ got reduce with increase in injection duration and $\mathrm{HC}$ increase with retard late injection timing. In phase $2, \mathrm{HRR}$ was half of the phase 1 value. Combustion in phase 2 got advanced, $\mathrm{NO}_{\mathrm{x}}$ got raise its value when injection duration increases and $\mathrm{NO}_{\mathrm{x}}$ got reduced with retard late injection timing. $\mathrm{HC}$ and $\mathrm{CO}$ got reduced with an increase in injection duration and both got an increase when injection timing got retard. Overall, the thermal efficiency of multiple injections was higher than single injection but lower than conventional injection. $\mathrm{HC}, \mathrm{CO}$, $\mathrm{NO}_{\mathrm{x}}$ and Smoke of multiple injections were lower than a single injection. Finally, experiment suggested that multiple injections were better than a single injection.

The main challenges faced on LTC are Controlling Combustion Phasing, Limited Load range operation, Transient control of operation, High level of $\mathrm{HC}$ and $\mathrm{CO}$ emissions and Fuel characteristics. In this combustion phasing was controlled by using dual injection and by multiple injection on LTC that result in bring up loss of thermal efficiency happened during LTC operation. High level of $\mathrm{HC}$ and $\mathrm{CO}$ emissions also controlled by changing some parameters like intake air 
temperature, pressure, geometry of engine and injection pressure and spray angle. Myung Yoon Kim A and Chang Sik Lee B (2007)too explored early injection but in arrange to decrease $\mathrm{HC}$ and $\mathrm{CO}$ outflows, divider wetting ought to be dodged, for that fuel injection weight utilized was kept at $100 \mathrm{Mpa}$ and fuel splash point was kept at $60^{\circ}$. The test was conducted on a single cylinder $\mathrm{Cl}$ engine with a coordinate injection at a consistent speed of $1500 \mathrm{rpm}$ and compression proportion of 15:1. Dual injection strategy was used in three modes of operations. In the first mode, a second injection (fuel injected $25 \%$ by mass) was injected at a constant timing at $10^{\circ} \mathrm{CA}$ aTDC and first injection (fuel injected $75 \%$ by mass) was injected in varying crank angle $50,60,70^{\circ} \mathrm{CA}$ bTDC. The moment mode of operation the primary injection was settled at $60^{\circ} \mathrm{CA} \mathrm{bTDC}$ and the moment injection changed from TDC to $20^{\circ} \mathrm{CA}$ aTDC. The ultimate mode of operation the primary injection was settled at $70^{\circ} \mathrm{CA}$ bTDC and moment injection was shifted from TDC to $20^{\circ} \mathrm{CA}$ aTDC. Results obtained using three mode of operation were higher IMEP was found with later first and early second injection timing that is first injection at $50^{\circ} \mathrm{CA}$ bTDC and second injection at TDC, advance the first injection would decrease IMEP because fuel wall wetting, IMEP decreased by retarding the second injection because shifting diffusion combustion to later side, COV IMEP increased when retarding second injection timing beyond $15^{\circ} \mathrm{CA}$ aTDC CO, $\mathrm{HC}$ emissions, and ISFC were increased steeply when first injection timing advance. $\mathrm{HC}$ diminished at to begin with injection timing settled at $50^{\circ} \mathrm{CA}$ bTDC and impede moment injection timing since retard the moment injection effectively burned remains $\mathrm{HC}$ show within the, to begin with, injection. $\mathrm{HC}$ expanded at, to begin with, injection timing settled at $70^{\circ} \mathrm{CA}$ bTDC and hinder moment injection timing since charge temperature was as well moo to burn the moment injection. Development moment injection timing diminishes CO. NOx diminishes with early, to begin with, injection and hinders the moment injection. At long last comparing all come about for way better IMEP and controlled emanations, ideal to begin with injection timing was at $50^{\circ} \mathrm{CA} \mathrm{bTDC}$ and moment injection timing was at afterward TDC or to begin with injection timing at $60^{\circ} \mathrm{CA}$ bTDC and moment injection at early. Changhwan Woo et al (2016)investigated the effect of intake air temperature and common-rail pressure on ethanol combustion in a single-cylinder light-duty diesel engine. The experiment was conducted on Single cylinder direct injection $\mathrm{Cl}$ engine with constant speed $2000 \mathrm{rpm}$ and BMEP of 426kPa, fuel used was ethanol. Dual injection strategies were used, the first injection injected at $170^{\circ} \mathrm{CA} \mathrm{bTDC} \mathrm{(80 \%} \mathrm{by} \mathrm{volume)} \mathrm{and} \mathrm{second} \mathrm{injection} \mathrm{injected}$ at $3^{\circ} \mathrm{CA}$ bTDC. First intake air temperature varied like $70,80,100^{\circ} \mathrm{C}$ and kept injection pressure constant at $50 \mathrm{MPa}$, test was conducted. Second fuel injection pressure varied like 50, 70, $100 \mathrm{MPa}$ and kept intake air temperature constant at $80^{\circ} \mathrm{C}$, test was conducted. Increase intake air temperature would increase peak pressure, HRR, improve engine efficiency and it also decrease $\mathrm{HC}, \mathrm{CO}$ emission, and $\mathrm{BSFC}$ but smoke and $\mathrm{NO}_{\mathrm{x}}$ slightly increased but lower than conventional diesel operation. Increase injection pressure would increase peak pressure, HRR, BSFC, HC, CO and Smoke, $\mathrm{NO}_{\mathrm{x}}$ emission. From all results found that intake air temperature $80^{\circ} \mathrm{C}$ and injection pressure $50 \mathrm{MPa}$ was optimum operating condition. Can Cinar Aet al (2015)explored impacts of admissions discuss temperature on combustion, execution, and emission characteristics of an $\mathrm{HCCl}$ motor fuelled with the mixes of $20 \% \mathrm{n}$-heptane and $80 \%$ isooctane powers? The test was conducted on single cylinder port injection with a steady speed of $1200 \mathrm{rpm}$. The fuel utilized was $20 \% \mathrm{n}$-heptane's and $80 \%$ isooctane. The test was conducted by changing the intake air temperature from 40 to $120^{\circ} \mathrm{C}$ in two lambda regard 0.6 and 0.7. Results found that increment admissions discuss temperature would increment PRR, HRR, in-cylinder temperature, and top weight and quicken a chemical response. Start timing and combustion were overwhelmed by incylinder gas temperature, weight, and blend composition. Increment admissions discuss temperature would diminish Top esteem of LTR, Combustion length decreased due to quickening a chemical response, SFC and $\mathrm{NO}_{\mathrm{x}}$ expanded at higher temperature due to progressed combustion (i.e.,) SOC absent from TDC and CO outflows increment to begin with at that point begun to decrease.

S. Swami Nathan et al (2010) examined the impacts of charge temperature and deplete gas re-circulation on combustion and emission characteristics of acetylene fuelled $\mathrm{HCCl}$ engine. The test was conducted on the single-cylinder engine that had a port injection with consistent speed $1500 \mathrm{rpm}$ and infusion weight of 220 bars. The fuel utilized as acetylene. Hot EGR was recycled by the external pipe. The experiment was conducted by shifting admissions charge temperature from $40^{\circ} \mathrm{C}-110^{\circ} \mathrm{C}$ to found the best esteem for each BMEP. Increasing intake charge temperature leads to increase thermal 
efficiency than baseline. $\mathrm{HC}$ emissions decrease with increment in admissions air temperature and $\mathrm{HC}$ emissions increment with an increment in EGR \%. CO outflows were exceptionally low compared to the pattern at tall BMEP. At moo BMEP CO emanations were high and increment with increment EGR\%. The warm productivity of the engine was continuously higher than the pattern with optimum charge temperature and EGR. Mustafa Canakci et al (2008) conducted an exploratory think about the impacts of boost weight on the performance and exhaust emissions of a DI$\mathrm{HCCl}$ gasoline engine. The test was conducted on a single cylinder coordinate injection motor with steady injection pressure $10 \mathrm{MPa}$ (splash point 60 ), admissions discuss temperature $119^{\circ} \mathrm{C}$, proportionality proportion 0.22 but shifting speed. The fuel utilized as gasoline. Intake air pressure varied as 101, 117, and $138 \mathrm{kPa}$, and injection timing shifted from 336 to $72^{\circ} \mathrm{CA}$ bTDC test was conducted. Results shown that increasing boost pressure would increase torque, increased power, BSFC reduced, combustion efficiency decreased and thermal efficiency increased. Start of combustion advanced while increasing boost pressure.

\section{Experimental Setup}

Engine used for the experiment was Kirloskar TAF1 model single cylinder, four-stroke air-cooled direct injection, diesel engine with a displacement volume of $661 \mathrm{~cm}^{3}$, developing $4.4 \mathrm{~kW}$ at $1500 \mathrm{rpm}$. The engine specifications are given in Table 2.1. Direct fuel injection well equipped with separate electronic control units was attached with the engine.

\section{Engine specification}

Table 2.1

Engine specification

Name of the engine KIRLOSKAR OIL ENGINES LTD
manufacturer

Type of Engine

Vertical, 4 stroke cycle, single acting, totally closed, high speed, Compression ignition diesel engine

No.of Cylinder 1

Bore $\quad 87.5 \mathrm{~mm}$

Stroke

$110 \mathrm{~mm}$

Cubic capacity

$661.5 \mathrm{~cm} 3$

Nominal Compression Ratio

17.5:1

Power output

4.7 kW@1500 rpm

Specific Fuel Consumption $\quad 265 \mathrm{~g} / \mathrm{kWh}$

Method of cooling Air cooled

Valve timing $\quad 4.5$

IVO bTDC $\quad 35.5$

IVC ABDC 35.5

EVO BBDC 3.5

EVC aTDC

The test engine furnished with AVL Data Acquisition System and PID controlled preheater system. Cylinder pressure was measured with AVL in-cylinder pressure transducer in combination with AVL charge amplifier. Optical AVL crank angle encoder was fixed to measure Crank angle. HFM 5 air flow sensor was fitted to measure Intake air flow. The intake and 
exhaust system surge tanks were equipped with K-type thermocouple for measuring temperature. The manifold temperature and Pressure were measured using bosch manifold air pressure sensor.

The AVL model 437c smoke meter was used for measuring Smoke. All gaseous emissions measurements were measure with an AVL 444 Di-gas Analyser which is shown in the Fig. 2.1.

\section{Engine operation}

Initially, the stationary engine had only mechanical fuel supply system which was converted into electronic fuel supply system and also it had injector, positioned in inclined which also converted into vertical. Readings were taken from the engine equipped with electronic fuel supply system with vertical positioned injector and best reading from that was taken as base reading for further comparison. LTC concept was introduced to reduce both $\mathrm{NO}_{\mathrm{x}}$ and smoke. It has three type methods to implement LTC in normal stationary engine, fueled with diesel. They are port injection, early injection and late injection. In this project late injection strategy was implemented. First in order to find the injection timing which was suitable for LTC, injection timing was retarded from normal base reading. After that injection timing which had low $\mathrm{NO}_{\mathrm{x}}$ and low smoke was fixed as main injection angle for dual injection mode. Later pilot injection timing range was found by retarding from base injection timing. Range of pilot injection timing was assigned by selecting range which had low NOx and low smoke. Then variation of two parameters was done within the range. Various operating parameters was shown in the Table 2.2. The base reading had injection timing of $13 \mathrm{deg}$ CA bTDC and fuel injection pressure of 400 bar. So, injection timing was retarded 2 deg CA after the base readings continuously until injection timing at which engine ran unstable. Maximum injection timing retard was -3 deg CA bTDC. Main injection timing was fixed as -3 deg CA bTDC. Because, in that injection timing NOemission and smoke were reduced higher compare to the other injection timing. After that dual injection had been implemented. Pilot injection timing was retard from base reading injection timing 13 deg. CA bTDC while main injection timing was kept at -3 deg. CA bTDC. Range of pilot injection timings had high thermal efficiency, low NO emission and low smoke than base readings were found. Where HC and CO outpourings did not change much. Pilot injection timings at 7, 5 and $3 \mathrm{deg}$. CA bTDC had best results. So, these three timings were used for further variation of parameters. Likewise mass fraction of pilot injection fixed as $0.15,0.10$ and 0.05 for further variation of parameters.

\section{Operating parameters}

Table 2.2

Operating Parameters for LTC combustion

\begin{tabular}{|lll|}
\hline Parameters & Single injection & Dual injection \\
\hline Pilot injection timings & nil & $7,5,3$ deg. CA bTDC \\
\hline Pilot injection mass fraction & nil & $0.15,0.1,0.05$ \\
\hline Main injection timings & $13,11,9,7,5,3,1,-1,-3$ deg. CA bTDC & -3 deg. CA bTDC \\
\hline Main injection mass fraction & 1 & $0.85,0.9,0.95$ \\
\hline Fuel injection pressure & $400 \mathrm{bar}$ & $400,500,600 \mathrm{bar}$ \\
\hline Intake air temperature & $310 \mathrm{~K}$ & $310,323,333 \mathrm{~K}$ \\
\hline Intake air pressure & $104 \mathrm{kPa}$ & $104 \mathrm{kPa}$ \\
\hline
\end{tabular}

So, this three-pilot injection timing and mass fraction were optimised in further process. The reading was taken for variation of parameters. They were fuel injection pressure and intake air temperature by keeping one parameter constant and vary the other parameter, where intake air pressure was kept constant as $104 \mathrm{kPa}$. Fuel injection pressure was varied as 400, 500 and 600 bar. Where intake air temperature was varied as $310 \mathrm{~K}, 323 \mathrm{~K}$ and $333 \mathrm{~K}$. Fuel injection pressure was 
limited to 600 bar because beyond that NO got increased and near to base reading. Likewise, intake air temperature limited to $333 \mathrm{~K}$ because beyond that smoke got increased above base reading.

\section{Engine Layout}

The engine layout used in this research is shown in the Fig. 2.1. The eddy current dynamometer, combustion measurement, performance measurement and emission measurement are also indicated here.

\section{Results And Discussions}

The results and discussions of the experimental setup and testing is discussed in this chapter.

\section{Optimization of main injection for LTC operation}

In-cylinder pressure and heat release rate were superimposed on the crank angle were appeared in Fig. 3.1.In-cylinder pressure were drop down as injection timing was retard, due to thermodynamic condition for combustion and during combustion already expansion stroke started which would reduce peak pressure. In Late injection, the combustion starts after TDC, which also reduce the peak pressure in cylinder. Heat release rate show that as injection timing was retard, premixed combustion was raised more than the diffusion combustion because fuel injected had some ignition delay. Injection timing retard made the fuel to inject in low temperature and pressure which make longer ignition delay. Peak HRR was obtained on -3 deg CA bTDC due to high premixed combustion.

Indicated thermal efficiency and emissions were shown in the Fig. 3.2.It shows that, when injection timing was retarded, the indicated thermal efficiency got drop down because, injection fuel were burn during expansion stroke of piston at which temperature and pressure inside cylinder was low and it affects combustion. That cause fuel consumption more result in loss in indicated thermal efficiency. Maximum loss of indicated thermal efficiency was $2 \%$ from base reading were observed.

Smoke got increased first when injection timing retarded up to 5 deg CA bTDC. After that it got reduced and reached equal to the base reading. Smoke first increase due to local air fuel mixture was rich as mixing was not proper when fuel burns close to TDC. As injection retard further ignition delay increase which made fuel well mixed with air result in reduction in smoke. $\mathrm{HC}$ and $\mathrm{CO}$ emissions did not show much difference. Maximum $\mathrm{HC}$ emission was 6 ppm only. Reason for low $\mathrm{HC}$ and $\mathrm{CO}$ emissions was due to higher air fuel ratio and engine used was air cooled, heat release from cylinder to atmosphere was low which maintain sufficient temperature inside cylinder. Since, vertical injector was used wall wetting of fuel was reduced. $\mathrm{CO}_{2}$ emission increased as injection timing was retarded due to higher fuel consumption. NO emission was reduced as injection retard due to low temperature of combustion. It was proved in many literatures.Comparing all the emissions, -3 deg CA bTDC had low NO emission and smoke. Though it had low thermal efficiency, would be increased on dual injection. So, -3 deg CA bTDC was kept as main injection timing for dual injection.

\section{Optimization of pilot injection timing, mass fraction, intake air temperature and fuel injection pressure for LTC operation}

Pilot injection timing was retard from base reading injection timing $13 \mathrm{deg}$. CA bTDC while main injection timing was kept at -3 deg. CA bTDC. Range of pilot injection timings had high thermal efficiency, low NO emission and low smoke than base readings were found. Where $\mathrm{HC}$ and $\mathrm{CO}$ emissions did not change much. Pilot injection timings at 7, 5 and 3 deg. CA bTDC had best results. So, these three timings were used for further variation of parameters. Likewise mass fraction of pilot injection fixed as $0.15,0.10$ and 0.05 for further variation of parameters.

So, this three-pilot injection timing and mass fraction were optimised in further process. The reading was taken for two variations of parameters. They were fuel injection pressure and intake air temperature by keeping one parameter constant and vary the other parameter, where intake air pressure was kept constant as $104 \mathrm{kpa}$. Fuel injection pressure 
was varied as 400, 500 and 600 bar. Where intake air temperature was varied as $310 \mathrm{~K}, 323 \mathrm{~K}$ and $333 \mathrm{~K}$. Fuel injection pressure was limited to 600 bar because beyond that NO got increased and near to base reading. Likewise, intake air temperature limited to $333 \mathrm{~K}$ because beyond that smoke got increased above base reading.

\section{Indicated Thermal Efficiency Optimization}

ITE for different injection pressure with respect to sweep in Start of injection angle 1(SOI-1) were shown in the Fig. 3.3. In that ITE got increased as fuel injection pressure was increased and also it increased when pilot injection timing retard from 7 deg. CA bTDC to 3 deg. CA bTDC. But it reduced as intake air temperature increased. The pilot mass fraction did not affect more on the ITE. Maximum ITE got increased was $9 \%$ higher than the base readings. ITE got increased when fuel injection pressure increased, due to good atomisation and well mixing of fuel, combustion efficiency got increased which reduce fuel consumption. It also shown Fig. 3.4, the cylinder pressure and HRR curve got increased as fuel pressure increased. Retard pilot injection timing increased ITE due to reducing the interval between pilot and main injection timing which did not allow

Pilot injection heat release to waste that was completely used by main injection. So, HRR got increased in second profile as pilot injection timing retard, this was shown in Fig. 3.4 ITE got reduced as intake air temperature increased, because intake air temperature increase would cause air density to reduce which directly affect the amount oxygen enter into the combustion chamber. Thus, due to less oxygen content combustion efficiency got reduced which required more fuel for combustion to attain same load and speed. This also affects reduction in cylinder pressure and HRR was shown in the Fig. 3.4.

\section{Combustion analysis by pilot injection, pilot injection mass, injection pressure, inlet temperature sweep}

Cylinder pressure and HRR for pilot injection timing sweep were shown same trends while varying other parameters. So, for example sweep of pilot injection timing was shown in Fig. 3.4by kept all other parameters constant. Normally, HRR had two curves, one was due to pilot injection and other was due to main injection. Likewise, cylinder pressure had two step rises in pressure one due to pilot injection and other due to main injection. As pilot injection timing retard, first curve rises of cylinder pressure reduced but second curve increased after 15 deg. CA aTDC. It also observed in HRR. HRR curve for pilot injection and main injection was retard as pilot injection timing retard. But main injection HRR curve got increased as pilot injection timing got retard. Because interval between two injections was reduced that make main injection fuel to use completely heat released from pilot injection fuel and made more combustion in main injection.

The pilot injection mass sweep in dual injection strategy keeping another parameter constant is shown in the Fig. 3.5. It was similar to pilot injection timing it had two curves in HRR, one due to pilot injection and other due to main injection. Pilot injection and main injection HRR curve increased as mass fraction of pilot injection increased. But start combustion remain constant. Cylinder pressure increased as mass fraction of pilot injection increased. Thus, the pilot injection mass fraction increase causes higher temperature and pressure during main injection that increase combustion efficiency and overall cylinder pressure.

The intake air temperature sweep in dual injection keeping another parameter constant is shown in the Fig. 3.6. It also had two HRR curves. HRR curves decreased as intake temperature increased due to less oxygen. Likewise, cylinder pressure decreased as intake air temperature increased.

Fuel injection pressure sweep while keeping other parameters constant was shown in Fig. 3.7.It also had two HRR curves. Two curves increased as fuel injection pressure increased. Similarly, cylinder pressure increased as fuel injection pressure increased due to good atomisation of fuel and well mixing. Combustion duration decreased as fuel injection pressure increased.

\section{Emission analysis by pilot injection, pilot injection mass, injection pressure, inlet temperature sweep}


$\mathrm{CO}$ emission for varying four parameters pilot injection timing, pilot injection mass fraction, fuel injection pressure and intake air temperature was shown in Fig. 3.8.It clearly shown that $\mathrm{CO}$ emission decreased as fuel injection pressure increased due to full utilisation of oxygen by well mixing. Likewise, $\mathrm{CO}$ emission decreased as pilot injection timing retard but not that much. Pilot injection mass fraction variation did not show any difference in $\mathrm{CO}$ emission.

$\mathrm{CO}_{2}$ emission was shown in Fig. 3.9.In all that case did not shown any big difference, because $\mathrm{CO}_{2}$ emission is depending upon fuel consumption and conversion of $\mathrm{CO}$ into $\mathrm{CO}_{2}$. Fuel consumption higher did not increase the $\mathrm{CO}_{2}$ emission. It was tally by $\mathrm{CO}$ emissions.

Overall analyzing all results optimized fuel injection pressure was 600 bar, optimized intake air temperature was $310 \mathrm{~K}$ and optimized intake air pressure was $107 \mathrm{kPa}$. In optimized value smoke reduced to $23 \%$, NO reduced to $63 \%$, CO reduced to $75 \%$ and ITE increased to $4 \%$ than base readings.

Table 3.1

Optimized values compared with base readings

\begin{tabular}{|lllllllllllll|}
\hline S.no. & $\begin{array}{l}\text { Intake air } \\
\text { temperature }\end{array}$ & $\begin{array}{l}\text { Intake } \\
\text { air } \\
\text { pressure }\end{array}$ & $\begin{array}{l}\text { Injection } \\
\text { pressure }\end{array}$ & $\begin{array}{l}\text { Pilot } \\
\text { injection } \\
\text { mass } \\
\text { fraction }\end{array}$ & $\begin{array}{l}\text { Pilot } \\
\text { injection } \\
\text { timing }\end{array}$ & ITE & CO & $\mathrm{CO}_{2}$ & $\mathrm{HC}$ & NO & Smoke \\
\hline Unit & $\mathrm{K}$ & $\mathrm{kpa}$ & bar & $\%$ & $\begin{array}{l}\text { Deg CA } \\
\text { bTDC }\end{array}$ & $\%$ & $\%$ & $\%$ & ppm & ppm & $\begin{array}{l}\text { \% of } \\
\text { opacity }\end{array}$ \\
\hline 1 & 310 & 104 & 400 & nil & nil & 30 & 0.04 & 5.1 & 3 & 597 & 9.6 \\
\hline 2 & 323 & 104 & 500 & 5 & 5 & 38 & 0.03 & 5.8 & 3 & 322 & 13.2 \\
\hline 3 & 310 & 104 & 500 & 5 & 5 & 31 & 0.02 & 4.38 & 1 & 187 & 10.2 \\
\hline 4 & 310 & 104 & 600 & 5 & 7 & 32 & 0.01 & 5.3 & 1 & 311 & 3 \\
\hline 5 & 310 & 107 & 600 & 5 & 5 & 34 & 0.01 & 4 & 1 & 220 & 7.1 \\
\hline
\end{tabular}

Table 3.1 shown the Optimized values compared with base readings. Table 3.1(s.no.1) represent base readings. Table 3.1 ( s.no.2) represent maximum ITE achieved that was $38 \%$ which was $8 \%$ higher than the base readings. At that condition NO emission reduced from 597 ppm to 322 ppm that was $47 \%$ reduction. But smoke still higher than the base readings.

Table 3.1 (s.no.3) represent lowest NO emission achieved which was $187 \mathrm{ppm}$ that was $68 \%$ reduction. But smoke still higher than the base readings. Table 3.1(s.no.4)represent lowest smoke achieved which was 3\% of opacity that was $75 \%$ reduction. At that conduction NO emission got reduced to 311 ppm which was $48 \%$ reduction, but ITE increased only $2 \%$ than base reading.

Table 3.1 (s.no.5) represent optimized value which had smoke reduced to $23 \%$, NO reduced to $63 \%$, $\mathrm{CO}$ reduced to $75 \%$ and ITE increased to $4 \%$ than base readings.

For optimized fuel injection pressure 500 and 600 bar, optimized pilot injection timing of 5 deg CA bTDC and optimized pilot injection mass fraction of 0.05 with varying intake air temperature and intake air pressure readings had been taken and results were discussed. Intake air pressure raised from $104 \mathrm{kPa}$ to $107 \mathrm{kPa}$.

The ITE at different intake air pressure, temperature and fuel injection pressure were shown in the Fig. 3.3. At 500 bar fuel injection pressure ITE got increased as intake air pressure increased. Intake air pressure $107 \mathrm{kPa}$ had ITE increased $1 \%$ compared to $104 \mathrm{kPa}$ intake air pressure at 500 bar fuel injection pressure. But at 600 bar fuel injection pressure there 
was no change in ITE at different intake air temperature and pressure. Maximum ITE attain was $4 \%$ higher than the base reading.

The optimized results for $\mathrm{CO}$ emission are shown in the Fig.. 3.8.CO emissions got reduced little when intake air pressure increase and intake air temperature increased. But their values were very small.

$\mathrm{TheCO}_{2}$ emissions got reduced as intake air pressure got increased. Increase in intake air temperature did not show much difference which is shown in the Fig.. 3.9.

Increases in the Intake air pressure would result in decrease of $\mathrm{HC}$ emissions and its optimized results are shown in the Fig.. 3.10. But intake air temperature increased would cause increase of HC emissions due to increases in the lean front area. $\mathrm{HC}$ emissions increase when injection pressure increases at high intake air temperature.

NO emissions got reduced as intake air pressure increased. Because all the fuel got burned later during expansion stroke was observed in heat release rate shown in Fig..3.11. NO emissions were increased as intake air temperature increased. Because $\mathrm{NO}$ emission is operated of temperature and element convenience.

Smoke emission is the one of the key factors in $\mathrm{Cl}$ engine operation and its optimization procedure is shown in the Fig. 3.12. At 500 bar fuel injection pressure smoke was little higher than the base reading. At 600 bar fuel injection pressure smoke was lower than the base reading. At 500 bar fuel injection pressure Smoke got reduced when intake air pressure increased due to more oxygen supply. At 600 bar fuel injection pressure smoke got increased as intake air pressure increase due to wall wetting. As intake air temperature increase smoke got increased.

Overall analyzing all results optimized fuel injection pressure was 600 bar, optimized intake air temperature was $310 \mathrm{~K}$ and optimized intake air pressure was $107 \mathrm{kPa}$. In optimized value smoke reduced to $23 \%$, NO reduced to $63 \%$, CO reduced to $75 \%$ and ITE increased to $4 \%$ than base readings are shown in the table 3.1 .

\section{Conclusions}

LTC using diesel fuel worked with late single injection strategy had less ITE compared with base readings. ITE increased maximum up to $8 \%$ compared to base readings by using late dual injection strategy. In all intake air temperature and fuel injection pressure, when pilot injection timing was retard from $7 \mathrm{deg}$. CA bTDC to 3 deg CA bTDC increase ITE, NO emission and decrease smoke. Likewise reducing mass fraction of pilot injection increase ITE, but reduce both NO emission and smoke. In all intake air temperature, if fuel injection pressure increase result in increase of ITE, NO emission and decrease of smoke, $\mathrm{CO}$ and $\mathrm{HC}$ emissions. In all intake air temperature and fuel injection pressure, if Intake air pressure increase result in increase of ITE, smoke and decrease of $\mathrm{NO}, \mathrm{HC}$ and $\mathrm{CO}$ emissions. Overall $\mathrm{CO}$ and $\mathrm{HC}$ emissions did not have much difference than base readings due to air-cooled engine with diesel fuel. It had enough temperature and oxygen content. Optimised pilot injection timing was $5 \mathrm{deg}$. CA bTDC and optimised pilot injection mass fraction was 0.05 . It was concluded by comparing all the results. Maximum ITE achieved was $38 \%$ at fuel injection pressure 500 bar, intake air temperature $323 \mathrm{~K}$ and intake air pressure $104 \mathrm{kPa}$. At that condition NO emission reduced from 597 ppm to 322 ppm, that was 47 \% reduction, but smoke still higher than the base readings. Lowest NO emission achieved was $187 \mathrm{ppm}$, that was $68 \%$ less than base reading at fuel injection pressure 500 bar, intake air temperature $310 \mathrm{~K}$ and intake air pressure $107 \mathrm{kPa}$. Lowest smoke achieved was $3 \%$ of opacity, that was $75 \%$ less than base reading at fuel injection pressure 600 bar, intake air temperature $310 \mathrm{~K}$ and intake air pressure $104 \mathrm{kPa}$. Overall comparing the results, optimised fuel injection pressure is 600 bar, intake air temperature is $310 \mathrm{~K}$, and intake air pressure is $107 \mathrm{kPa}$. At that condition, smoke reduced to $23 \%$, NO reduced to $63 \%$, CO reduced to $75 \%$ and ITE increased to $4 \%$ compared to base readings. 


\section{Scope For The Future Work}

The scope for the future work of this research is given below.

- Experiment can be performed beyond $50 \%$ load because optimization is very difficult at higher load engine operation.

- Multiple late injections strategy on LTC can be studied because that helps for regeneration of diesel particulate filter.

- In this research multiple injection strategy performed only for diesel but this can be performed for alternative fuels on dual injection strategy.

- In addition to this in-cylinder techniques, after treatment can be studied for the effective reduction of harmful pollution from the diesel engine.

\section{Declarations}

\section{Ethics approval and consent to participate}

Not Applicable.

\section{Consent to publication}

Not Applicable.

\section{Author's contributions}

Bharathiraja Moorthy handled conceptualization, methodology, and testing as well as data collection. Nithyanandhan Kamaraj was responsible for experimental setup, testing, writing, reviewing and final editing of the manuscript. Somasundaram Periasamy was in responsibility of data collection, data analysis and preliminary paper writing, while Saji Raveendran Padmavathy was in control of consolidating the results and result interpretation. Gaurav Dwivedi involved in the analysis and editing of the manuscript. The methodology and data gathering were the responsibility of Ranjithkumar Subramaniam. The final manuscript was read and approved by all of the authors.

\section{Funding}

- There is no financial assistance for this article.

\section{Competing interests}

The authors declare that they have no competing interests.

\section{Availability of Data and Materials}

The data set generated during this work are not publicly available, however they are available upon reasonable request to the corresponding author.

\section{Acknowledgements}

The authors accept the testing and infrastructure facilities provided by Bannari Amman Institute of Technology, Sathyamangalam and Kongu Engineering College, Erode during this work.

\section{References}


1. Canakci M (2008) An experimental study for the effects of boost pressure on the performance and exhaust emissions of a DI-HCCI gasoline engine. Fuel 87:1503-1514. https://doi.org/10.1016/j.fuel.2007.08.002

2. Cinar C, Uyumaz A, Solmaz H et al (2015) Effects of intake air temperature on combustion, performance and emission characteristics of a $\mathrm{HCCl}$ engine fueled with the blends of $20 \% \mathrm{n}$-heptane and $80 \%$ isooctane fuels. Fuel Process Technol 130:275-281. https://doi.org/10.1016/j.fuproc.2014.10.026

3. Das P, Subbarao PMV, Subrahmanyam JP (2015) Effect of main injection timing for controlling the combustion phasing of a homogeneous charge compression ignition engine using a new dual injection strategy. Energy Convers Manag 95:248-258. https://doi.org/10.1016/j.enconman.2015.02.018

4. Dec JE (2009) Advanced compression-ignition engines - Understanding the in-cylinder processes. Proc Combust Inst 32 Il:2727-2742. https://doi.org/10.1016/j.proci.2008.08.008

5. Ganesh D, Nagarajan G, Ganesan S (2014) Experimental investigation of homogeneous charge compression ignition combustion of biodiesel fuel with external mixture formation in a $\mathrm{Cl}$ engine. Environ Sci Technol 48:3039-3046. https://doi.org/10.1021/es403104f

6. Hasan MM, Rahman MM (2016) Homogeneous charge compression ignition combustion: Advantages over compression ignition combustion, challenges and solutions. Renew Sustain Energy Rev 57:282-291. https://doi.org/10.1016/j.rser.2015.12.157

7. Kim MY, Lee CS (2007) Effect of a narrow fuel spray angle and a dual injection configuration on the improvement of exhaust emissions in a $\mathrm{HCCl}$ diesel engine. Fuel 86:2871-2880. https://doi.org/10.1016/j.fuel.2007.03.016

8. LEE TYK and SH (2012) Combustion and Emission Characteristics of Wood Pyrolysis Oil-Butanol Blended Fuels in a Di Diesel Engine. Int J ... 0. https://doi.org/10.1007/s12239

9. Mathivanan K, Mallikarjuna JM, Ramesh A (2016) Influence of multiple fuel injection strategies on performance and combustion characteristics of a diesel fuelled $\mathrm{HCCl}$ engine - An experimental investigation. Exp Therm Fluid Sci 77:337-346. https://doi.org/10.1016/j.expthermflusci.2016.05.010

10. Yahya SM (1982) Fundamentals of Compressible Flow

11. Swami Nathan S, Mallikarjuna JM, Ramesh A (2010) Effects of charge temperature and exhaust gas re-circulation on combustion and emission characteristics of an acetylene fuelled $\mathrm{HCCl}$ engine. Fuel 89:515-521. https://doi.org/10.1016/j.fuel.2009.08.032

12. Turkcan A, Ozsezen AN, Canakci M (2013) Effects of second injection timing on combustion characteristics of a two stage direct injection gasoline-alcohol HCCl engine. Fuel 111:30-39. https://doi.org/10.1016/j.fuel.2013.04.029

13. Woo C, Kook S, Hawkes ER (2016) Effect of intake air temperature and common-rail pressure on ethanol combustion in a single-cylinder light-duty diesel engine. Fuel 180:9-19. https://doi.org/10.1016/j.fuel.2016.04.005

\section{Figures}




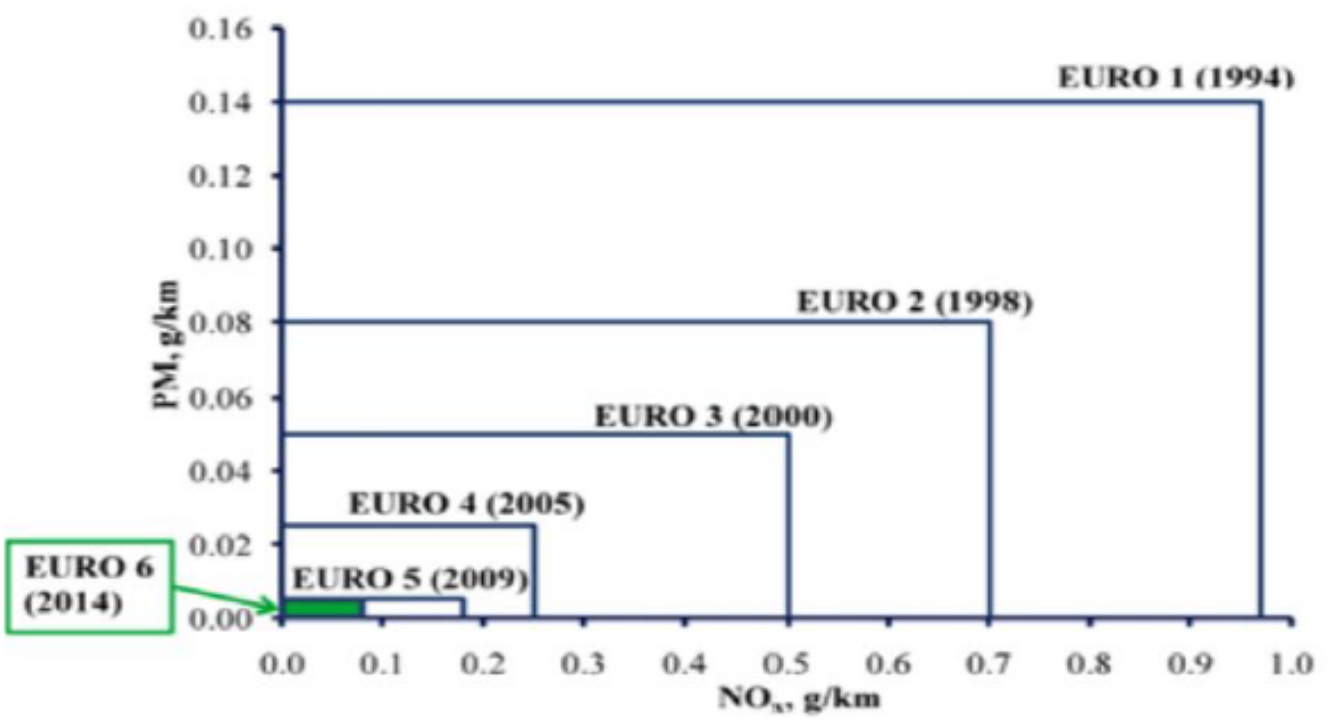

Figure 1

Euro emission norms 


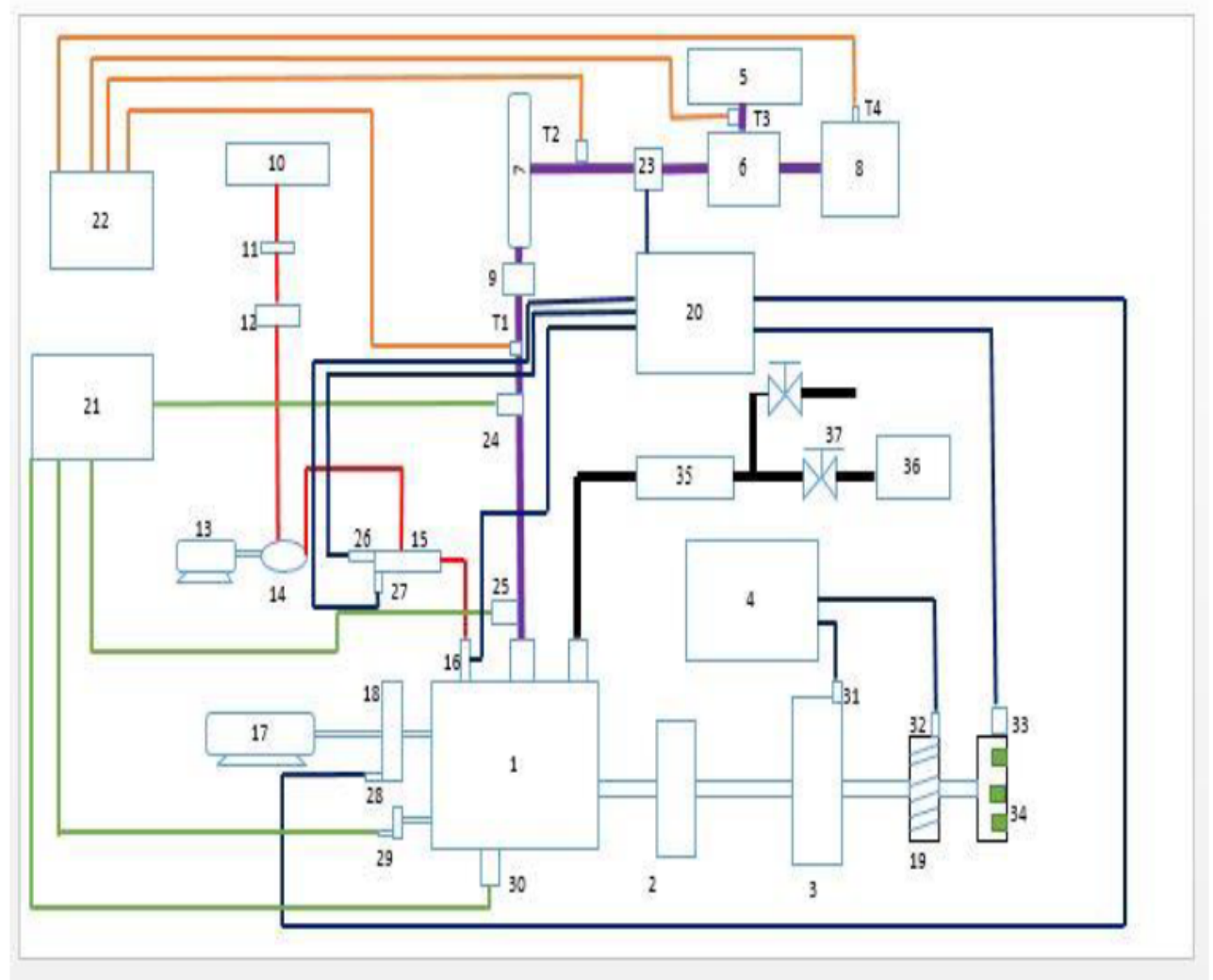

\begin{tabular}{|c|l|}
\hline $\begin{array}{c}\text { PART } \\
\text { NO }\end{array}$ & DESCRIPTION \\
\hline 1 & Engine \\
\hline 2 & Flyrtheel \\
\hline 3 & Eddy current dynamometer \\
\hline 4 & Dynamometer control \\
\hline 5 & Intake air boosting unit \\
\hline 6 & Control value \\
\hline 7 & Air pre-heater \\
\hline 8 & Air surge tank \\
\hline 9 & Pressure regulator \\
\hline 10 & Diesel tank \\
\hline 11 & Fuel filter \\
\hline
\end{tabular}

\begin{tabular}{|c|l|}
\hline 12 & Feed pump \\
\hline 13 & Motor to drive pump \\
\hline 14 & High preasure pump \\
\hline 15 & CRDI \\
\hline 16 & Fuel injector \\
\hline 17 & Starter motor \\
\hline 18 & Cam wheel \\
\hline 19 & Speed sensor wheel \\
\hline 20 & ECU \\
\hline 21 & Combustion analysis system \\
\hline 22 & Temperature Indicator \\
\hline 23 & Air mass flow sensor \\
\hline 24 & MAP sensor \\
\hline
\end{tabular}

\begin{tabular}{|c|l|}
\hline 25 & Inlet pressure sensor \\
\hline 26 & Pressure control value \\
\hline 27 & Rail pressure sensor \\
\hline 28 & Cam position sensor \\
\hline 29 & Crank angle encoder \\
\hline 30 & In cylinder pressure sensor \\
\hline 31 & Load sensor \\
\hline 32 & Speed sensor \\
\hline 33 & Crank position sensor \\
\hline 34 & Target wheel \\
\hline 35 & Exhaust surge tank \\
\hline 36 & Gas analyzer \\
\hline 37 & Control value \\
\hline
\end{tabular}

Figure 2

Engine Layout 


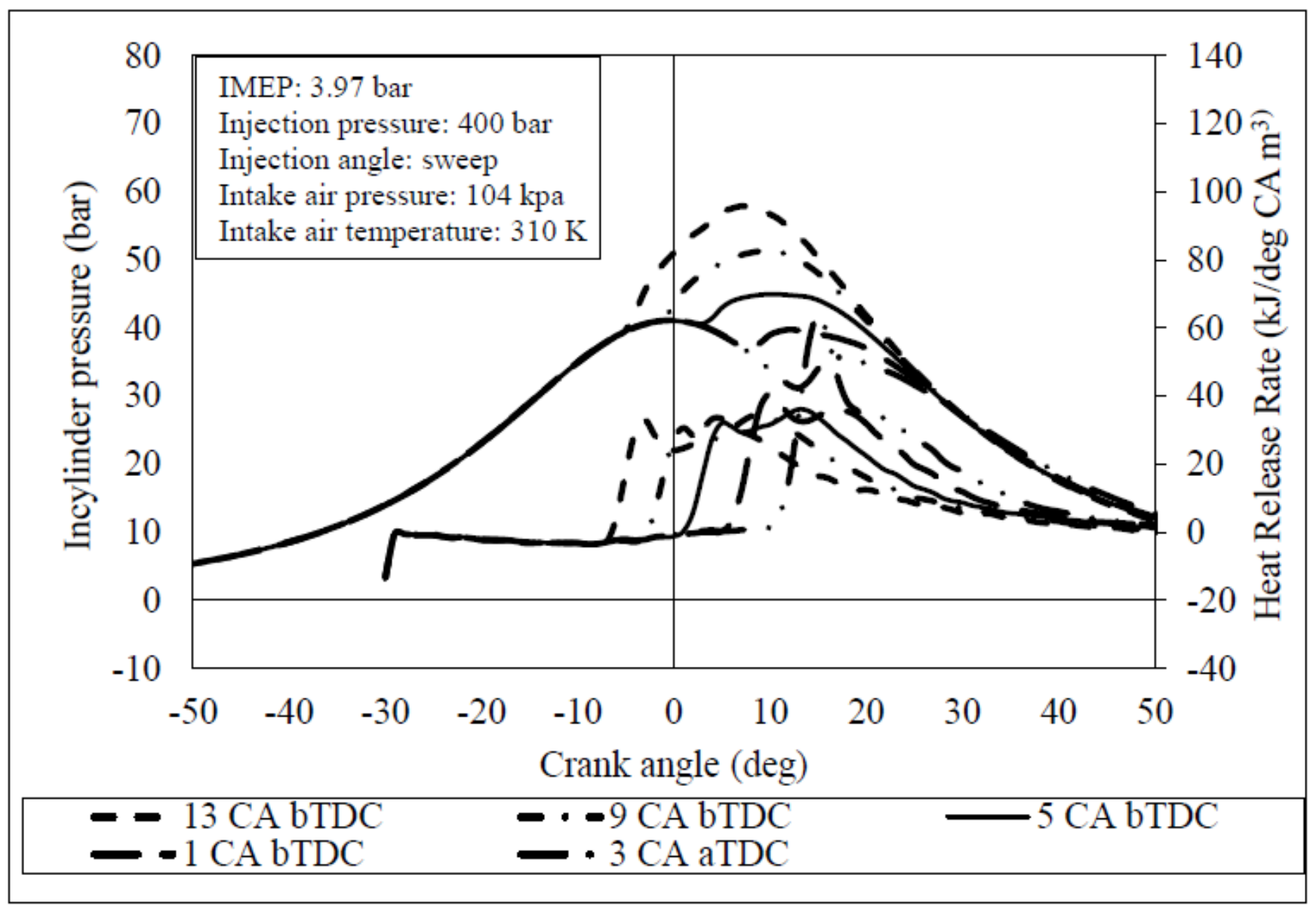

Figure 3

In-cylinder pressure and HRR for retardation of single injection to optimize main injection for LTC operation 

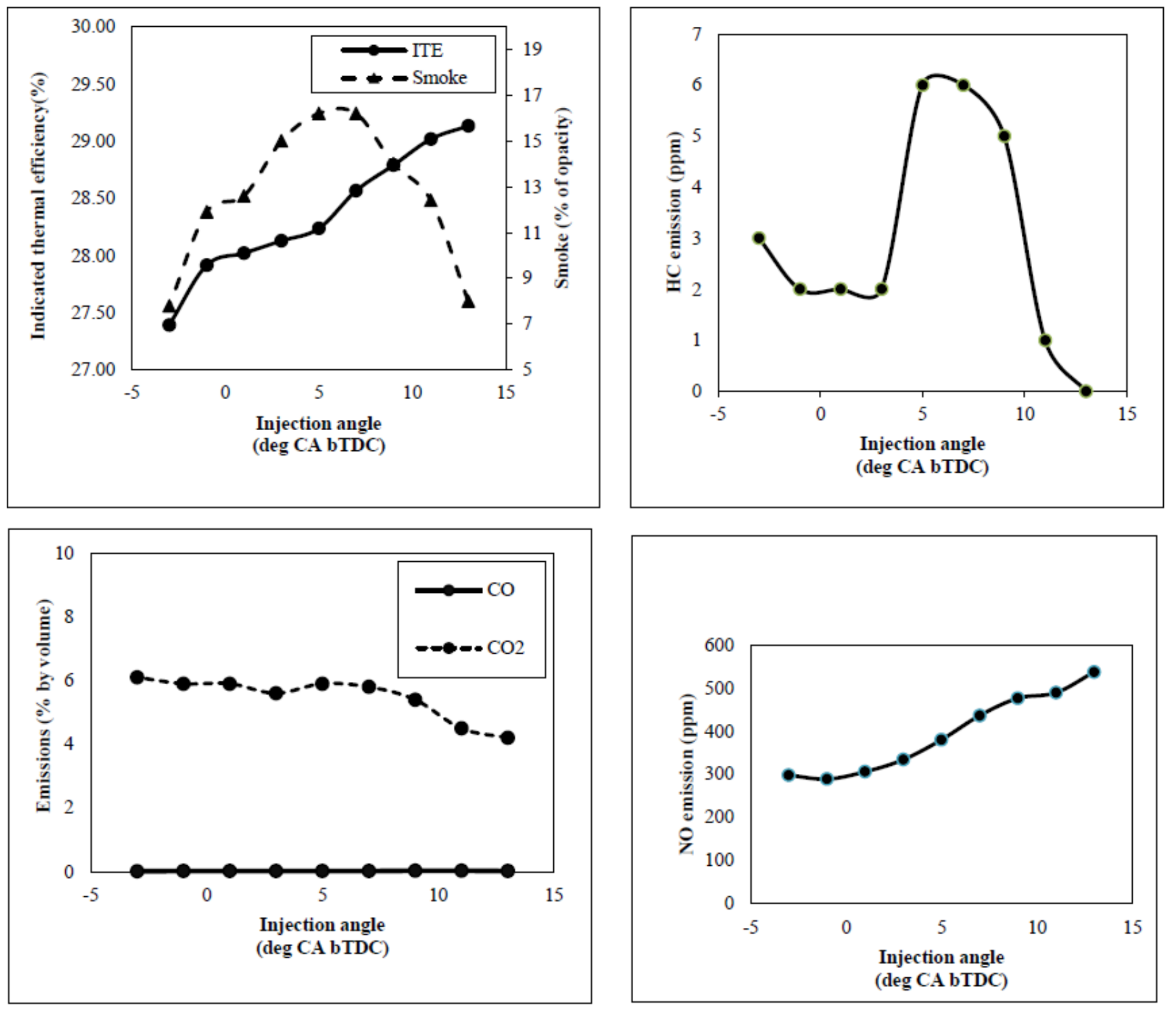

Figure 4

Indicated thermal efficiency and emissions for retardation of single injection timing 

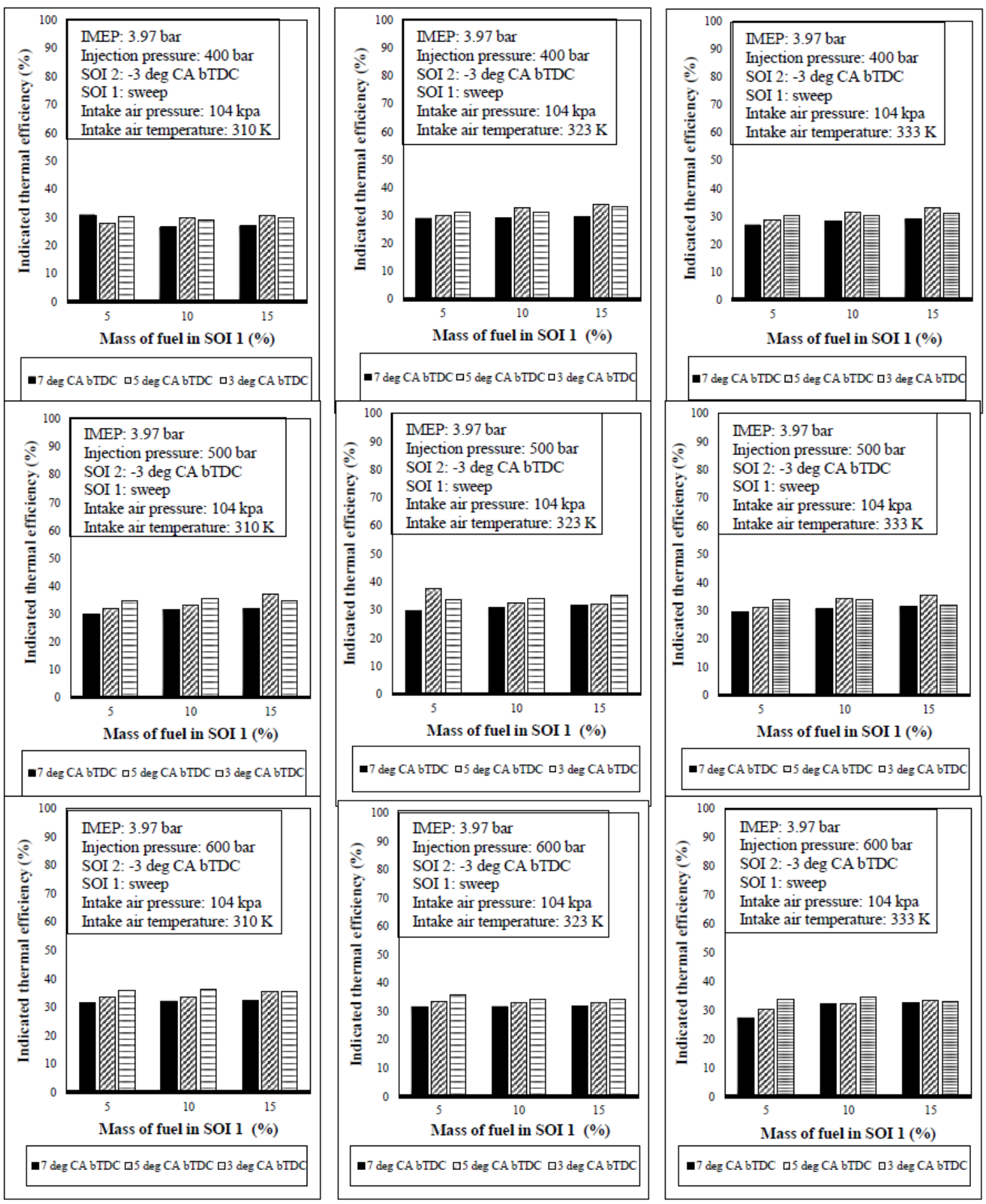

Figure 5

Variation of ITE for dual injection with respect to different injection pressure and SOI-1. 


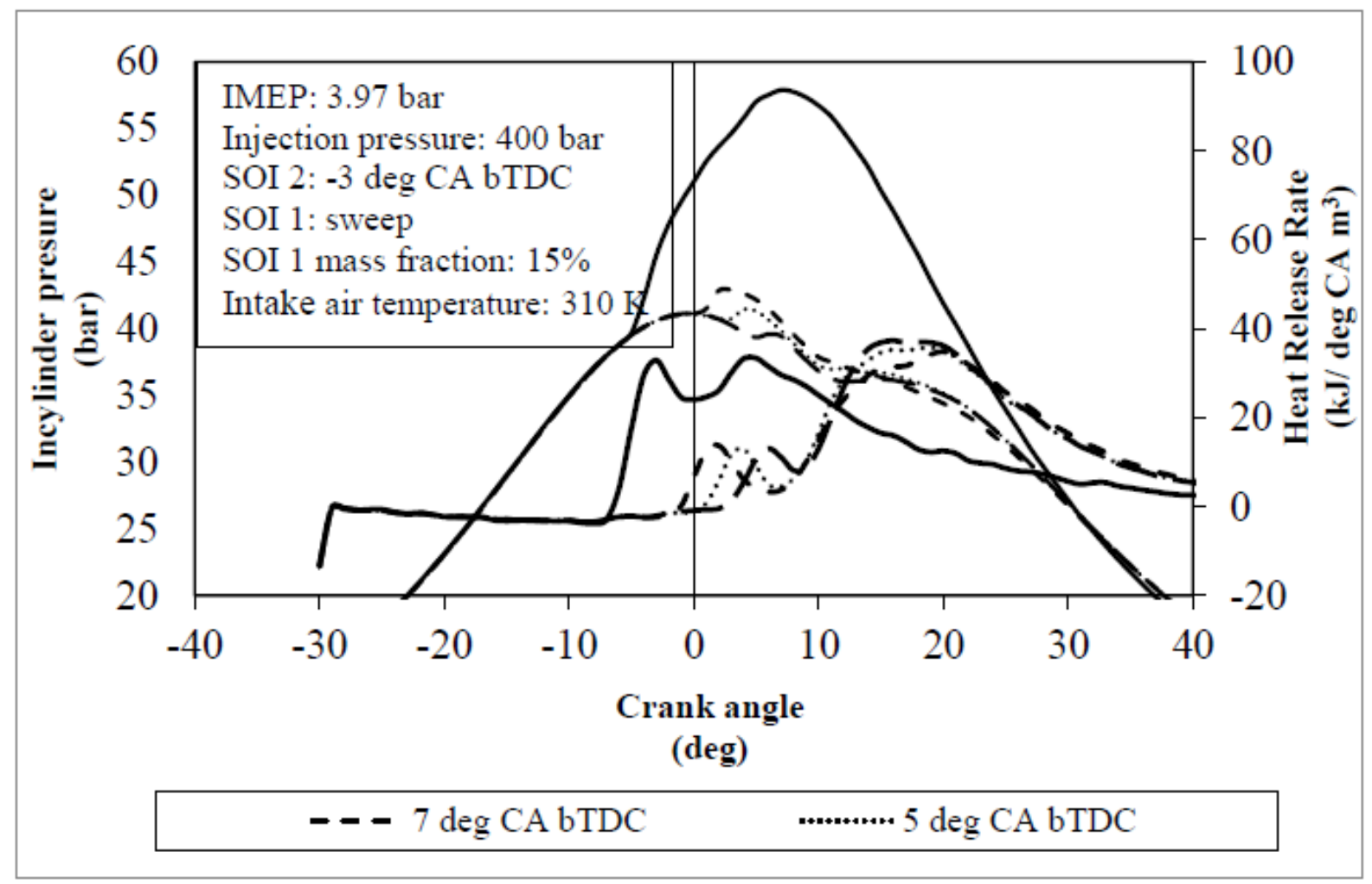

Figure 6

Cylinder pressure and HRR for dual injection, pilot injection timing sweep

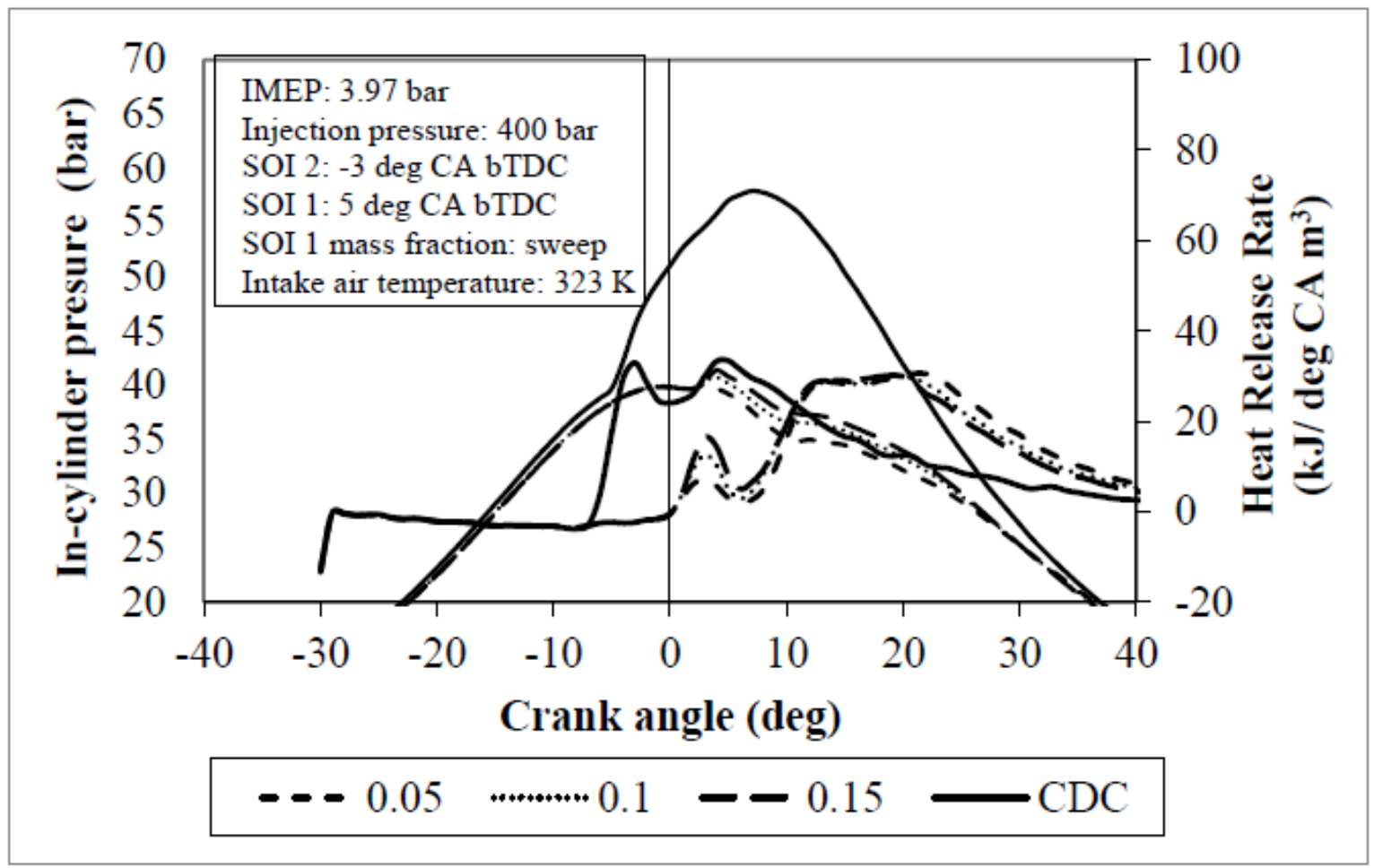

Figure 7

Cylinder pressure and HRR for dual injection for pilot injection mass sweep 


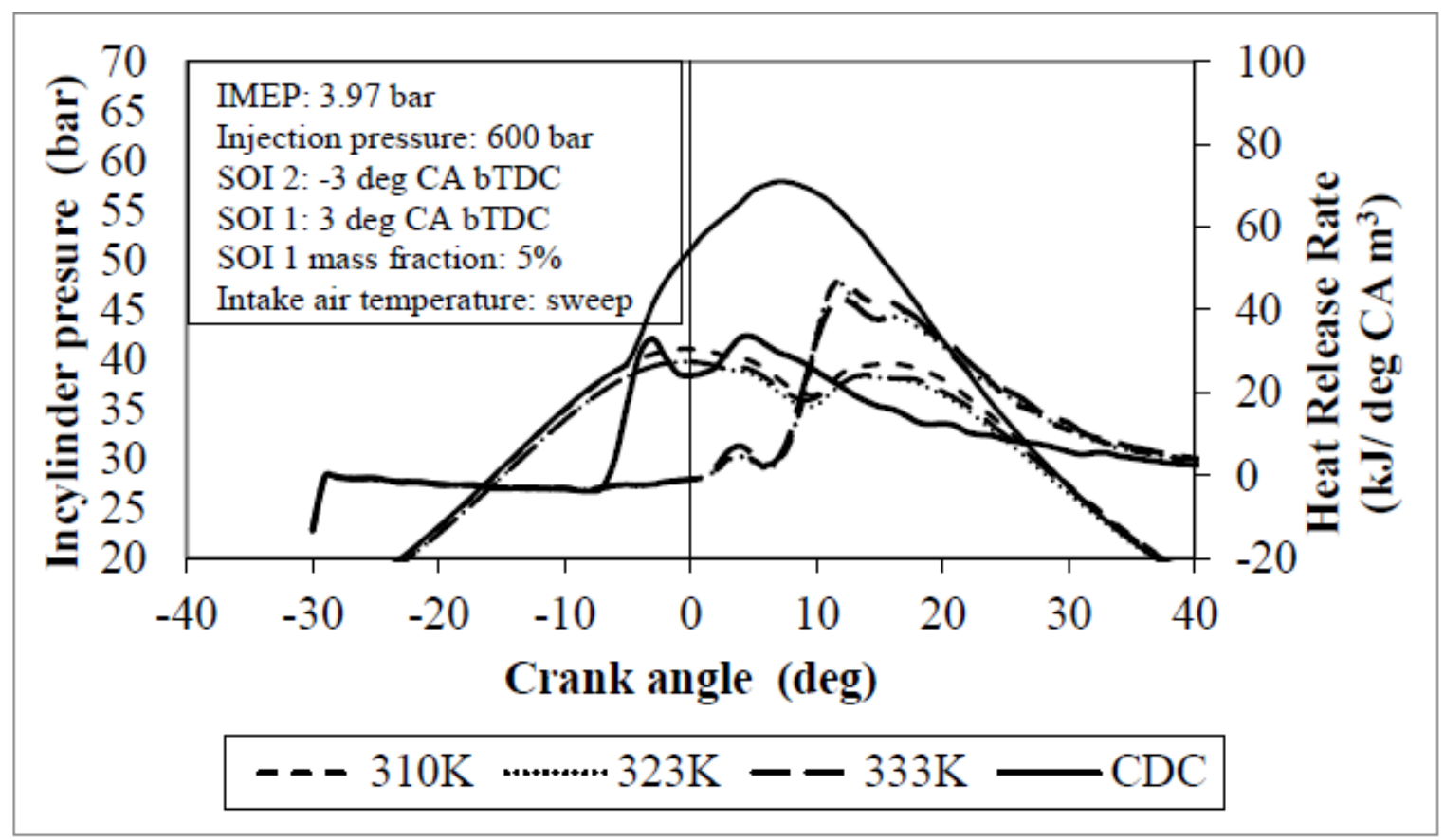

Figure 8

Cylinder pressure and HRR for dual injection, intake air temperature sweep

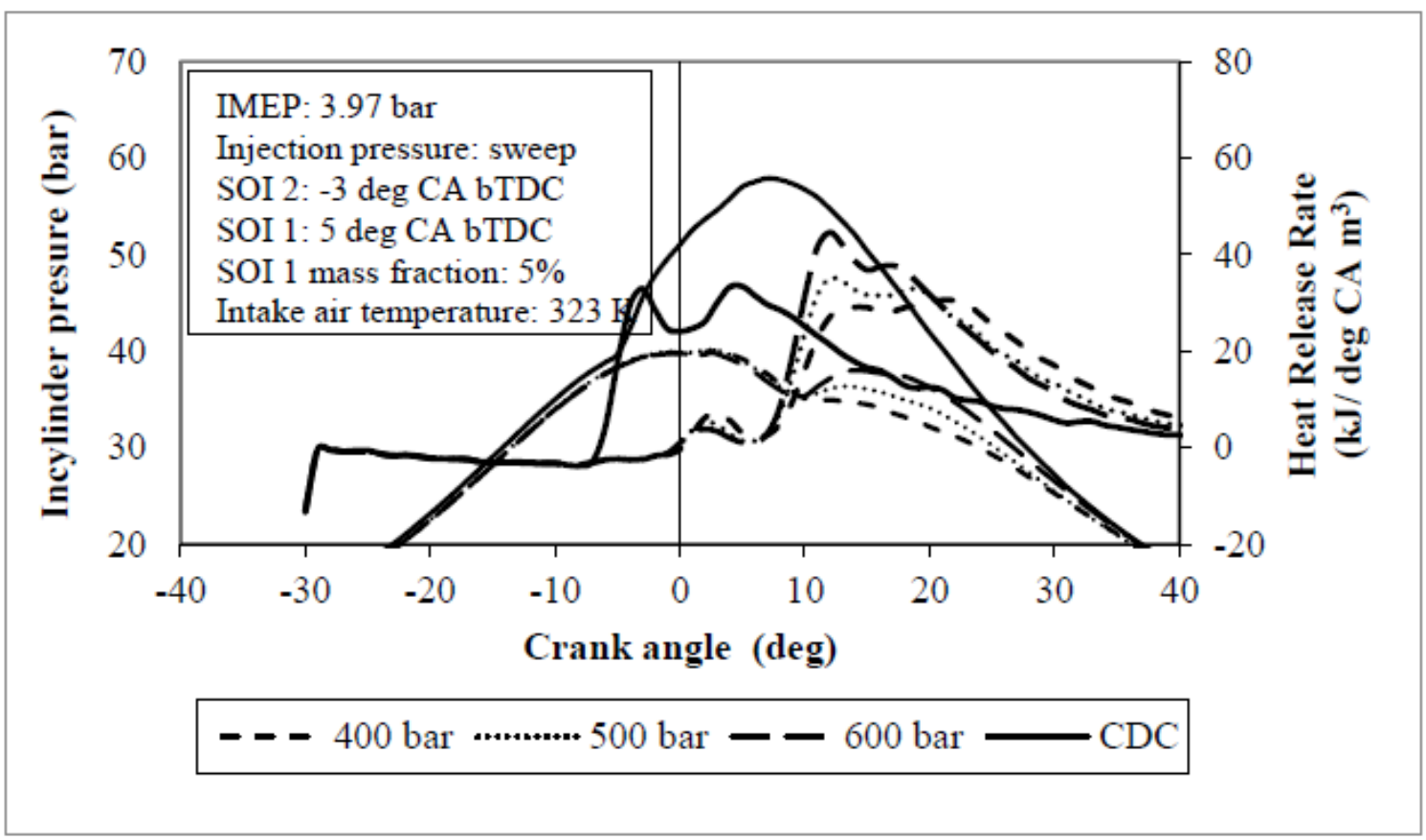

Figure 9

Cylinder pressure and HRR for dual injection, fuel injection pressure sweep 


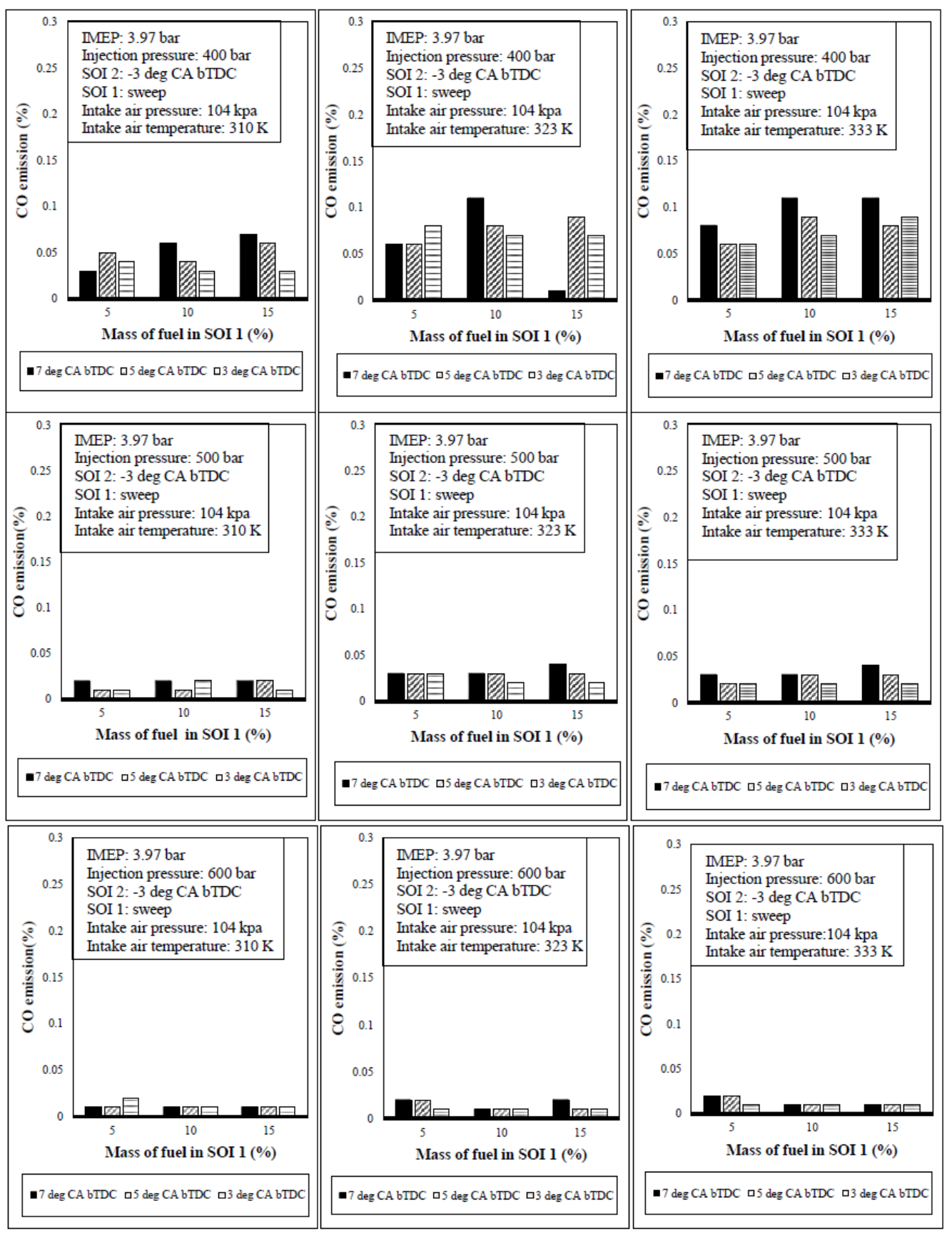

Figure 10

Optimization of $\mathrm{CO}$ emission with respect to different parameters 


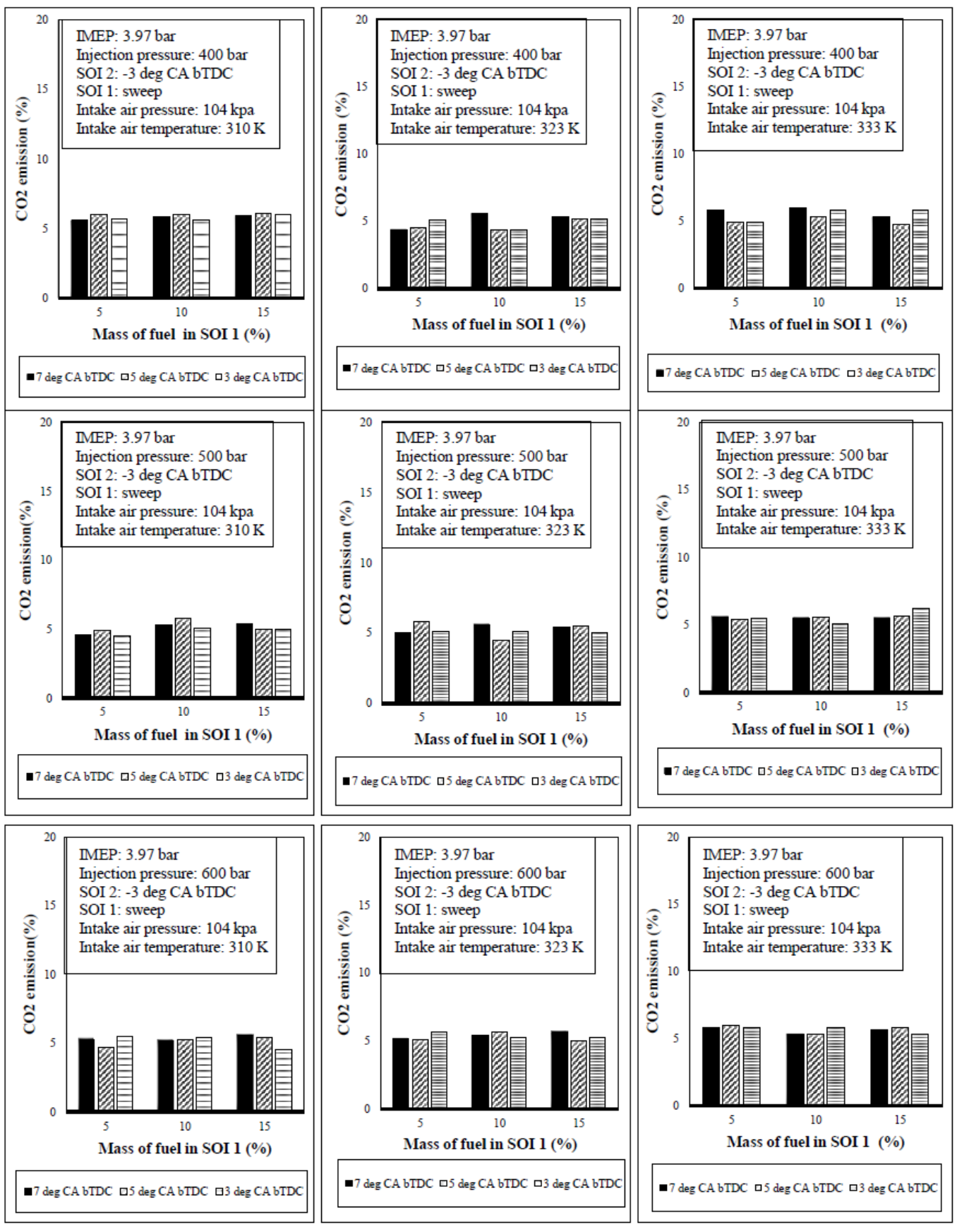

Figure 11

Optimization of $\mathrm{CO} 2$ emission by varying different parameters 

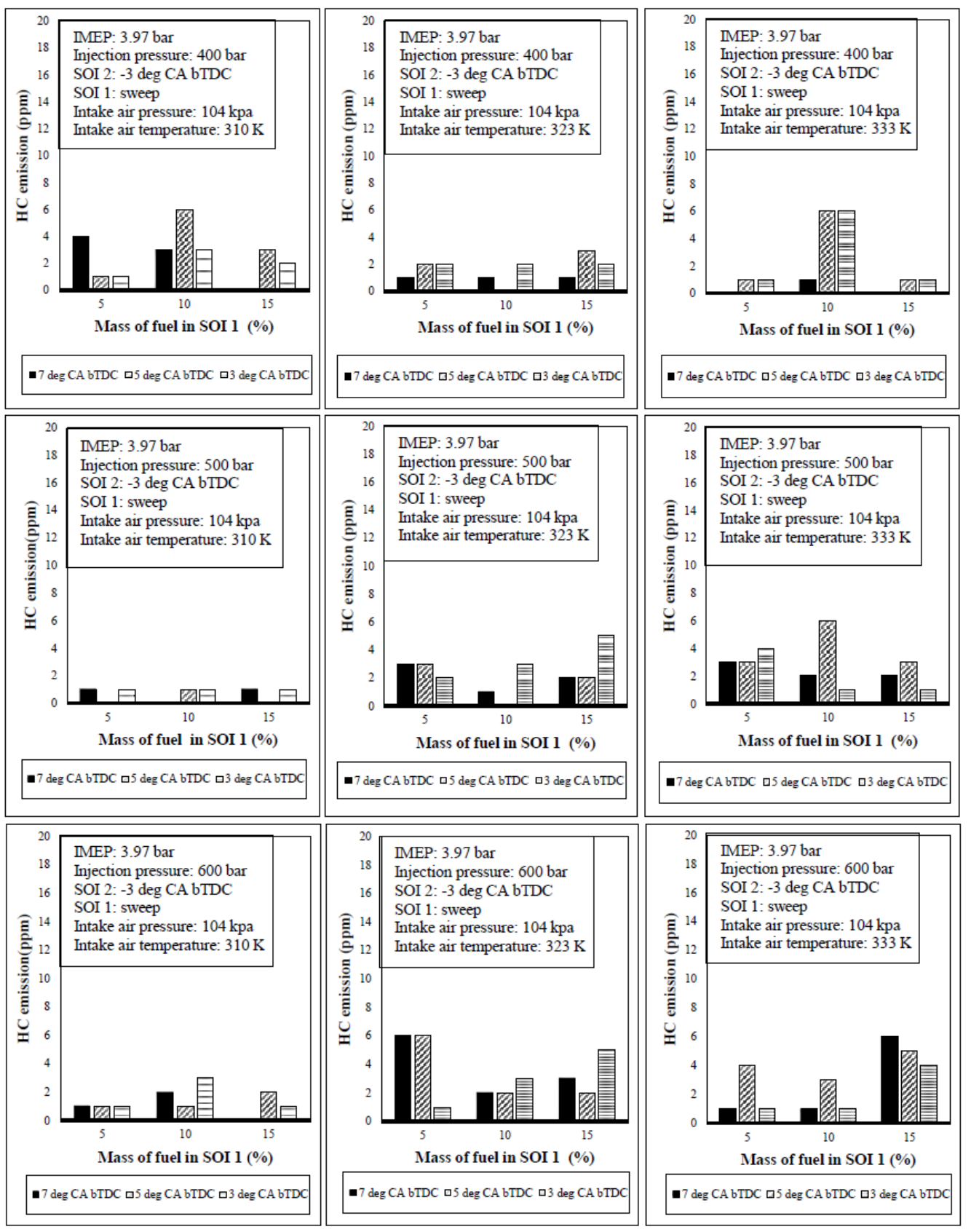

Figure 12

Optimization of $\mathrm{HC}$ emission by varying different parameters 


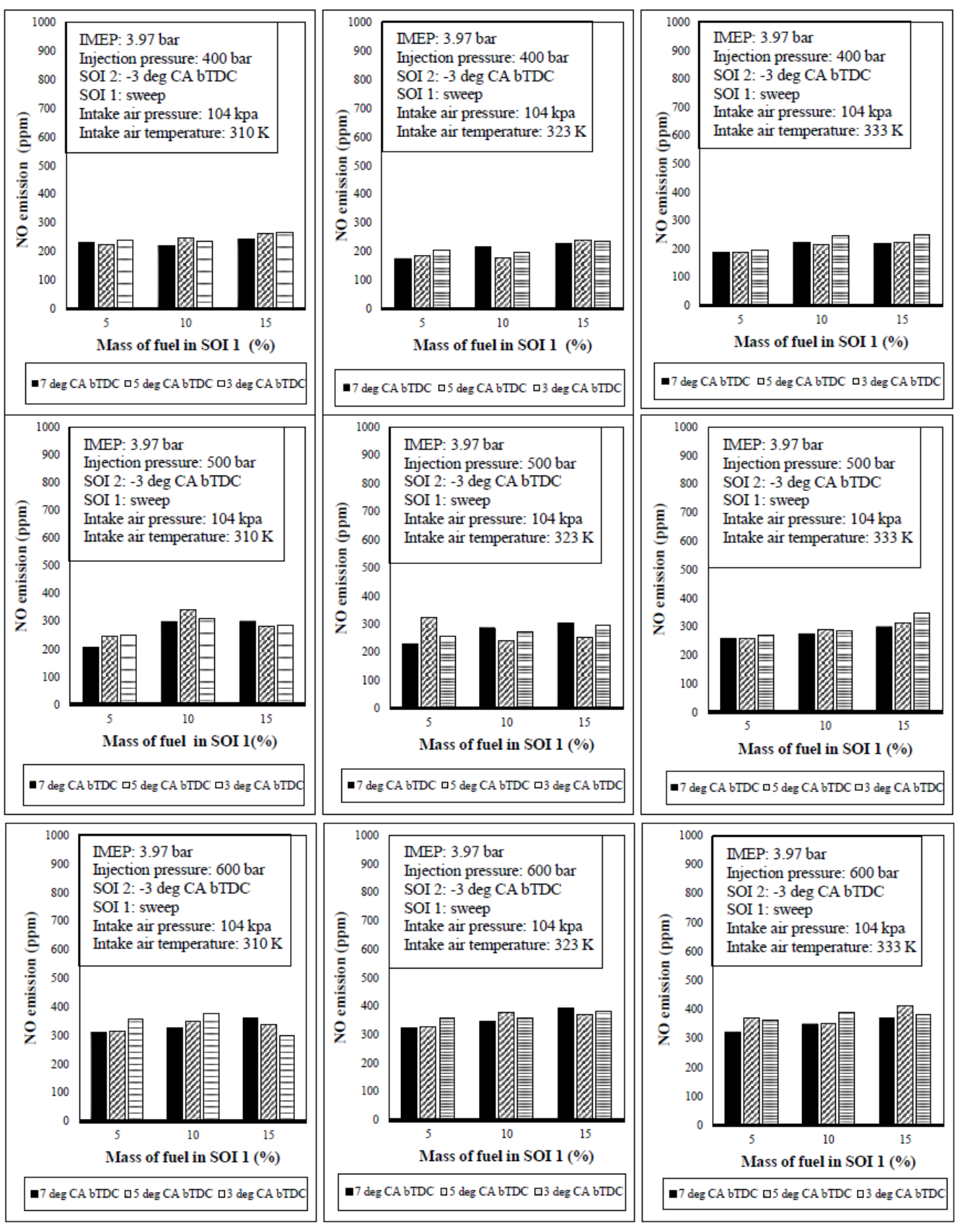

Figure 13

Optimization of $\mathrm{NO}$ emission by varying different parameters 


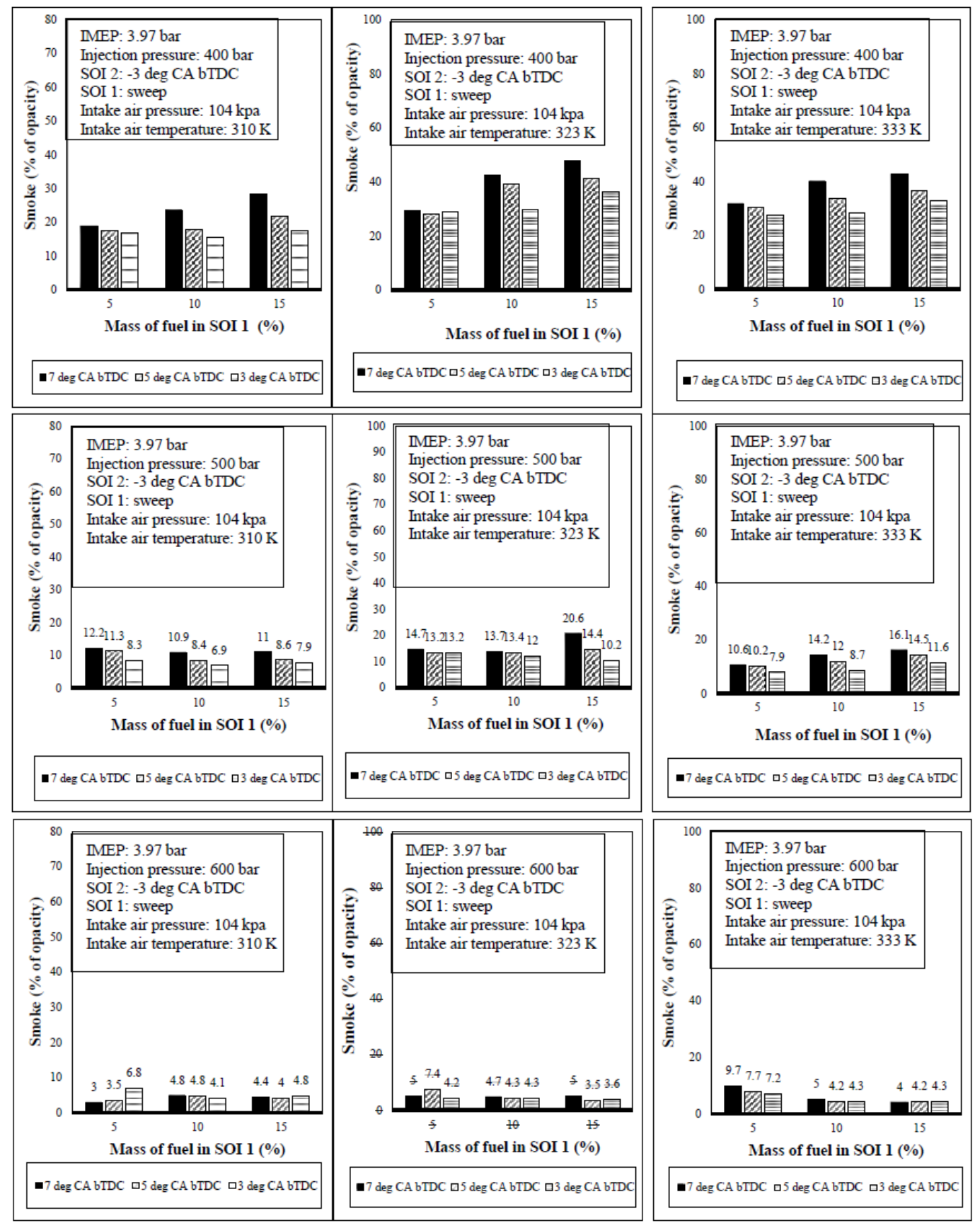

Figure 14

Optimization of smoke emission by varying different parameters 